\title{
Negacionismo viral e política exterminista: notas sobre o caso brasileiro da Covid-19
}

\section{Viral denialism and exterminist politics: remarks on the Brazilian case of Covid-19}

\section{Thor João de Sousa Veras*}

Resumo: A pandemia da covid-19 ao redor do mundo suscitou na esfera pública uma profusão de discursos negacionistas da parte de lideranças políticas que foram seguidos pela sociedade civil. Ao situar essa manifestação no contexto social mais amplo da emergência de uma nova dinâmica política marcada por regimes de democracias iliberais, o objetivo desse texto é apresentar os aspectos filosóficos que subjazem o discurso negacionista na experiência brasileira mais recente. Tendo como base uma crítica obscurantista do progresso e uma filosofia da história retrógrada e conspiracionista, essa constelação filosófica tornouse legitimador da extrema-direita internacional e, em especial no Brasil, do bolsonarismo.

Palavras-chave: Negacionismo; Populismo; Exterminismo; Tradicionalismo; Covid-19

Abstract: The covid-19 pandemic around the world has sparked in the public sphere a profusion of denialists speeches by political leaders and civil society in general. By placing this manifestation in the broader social context of the emergence of a new political dynamic marked by regimes of illiberal democracies, the purpose of this text is to present the philosophical aspects that underlie the denialist discourse in the most recent Brazilian experience. The core of this phenomenon consists of a backward and conspiracyist ideology, which from the traditionalist and perennialist philosophies, were the basis of the legitimizing discourse of the international extreme right and, especially in Brazil, of Bolsonarism.

Keywords: Denialism; Populism; Exterminism; Traditionalism; Covid-19

\begin{abstract}
Minha campanha foi baseada em um versículo bíblico: "Você conhecerá a verdade, e a verdade os libertará". Sempre sonhei em libertar o Brasil da ideologia nefasta da esquerda. Uma das minhas maiores inspirações está à minha direita, o professor Olavo de Carvalho. Ele é admirado pelos jovens do Brasil e em grande parte devemos a ele a revolução que estamos vivendo hoje. [...] Humildemente; sabemos que, quando a democracia não dá muito certo, na retaguarda tem as Forças Armadas (risos). Sempre seguimos lado a ladol. (Discurso de Jair Bolsonaro na Embaixada brasileira dos Estados Unidos, 17 de Março de 2019)
\end{abstract}

Em "Notas sobre o exterminismo, estágio final da civilização", o historiador inglês E. P. Thompson ensaiava as linhas gerais da emergência de um novo modelo de sociedade que estaria à beira de extinção. A disputa geopolítica em voga na guerra fria entre as nações capitalistas e comunistas impulsionavam uma lógica de governo, cuja prática sistemática estava relacionada ao extermínio de multidões. Tal espírito do tempo levou Thompson a elaborar em torno da categoria de "exterminismo" um arcabouço teórico capaz de apreender as "tecnologias do apocalipse" que aceleram o fim da civilização. Essa catástrofe para o autor não aconteceria "acidentalmente (mesmo que o disparo final seja "acidental"), mas como a

${ }^{1}$ GORTÁZAR, Naiara. Bolsonaro visita Trump para reforçar aliança do Brasil com os EUA Disponível em: https://brasil.elpais.com/brasil/2019/03/17/politica/1552860249 721017.html Cf. FELTRAN, Gabriel. The revolution we are living

*Doutorando em Filosofia na Universidade Federal de Santa Catarina, Florianópolis, SC. E-mail: thor.verass@gmail.com ORCID: https://orcid.org/oooo-0003-0710-3822 
consequência direta de atos anteriores da política, do aperfeiçoamento dos meios de extermínio, e da estruturação de sociedades inteiras de modo a estarem dirigidas para esse fim”2. Em nosso contexto, podemos afirmar que acúmulo de tais práticas políticas herdadas no século XXI não ficaram retidas simplesmente a ameaça da bomba atômica.

Pois é justamente a iminência do colapso climático acentuado pelo aquecimento global que trouxe ao centro do debate social uma perspectiva do fim do mundo 3 , isto é, do esgotamento do planeta e das condições materiais de existência da espécie humana. Mesmo diante da pluralização de formas de vida e da integração social promovida pela globalização neoliberal, a natureza atroz desse fenômeno e as consequências ecologicamente catastróficas expuseram uma verdade inconveniente para governos populistas da ultradireita que, como continuação da política exterminista, aderiram a práticas sistemáticas de negacionismo ambiental em função da exploração irrestrita dos recursos naturais e do desenvolvimento desenfreado da industrialização como destruição do planeta.

Essas práticas de negação da modernidade e da razão pública ${ }^{4}$ acompanham a emergência de um novo cenário histórico global que se apresenta diferente das três anteriores ondas de populismo radicais de direita, isto é, do fascismo de Mussolini, Salazar e Franco entre 1945-55, do populismo de direita dos anos 1955-80, de figuras anticomunistas como Joseph McCarthy e partidos europeus de direita do pós-guerra e de figuras expressamente de direita radical que estiveram nas disputas partidárias entre 1980-2000 ao redor do mundo, como a família Le Pen, o partido Austríaco da Liberdade e movimentos holandeses anti-imigração. As novas figuras no cenário contemporâneo representadas por Órban, Modi, Bolsonaro, Trump e Putin e seus respectivos partidos, são agora considerados parte do mainstream (embora se coloquem como anti-establishment) e normalizados como forças políticas que tem um potencial de estabilidade e domínio relevantes.

Nesse horizonte, eles representam uma quarta onda de populismo ${ }^{5}$ que foi organizada como resposta à três recentes crises globais: os ataques terroristas de 11 de setembro nos EUA, a grande recessão de 2008 e a crise de refugiados de 2015. Altamente ideológica, tais líderes oferecem narrativas messiânicas e salvacionistas, que variam dadas as especificidades locais dos respectivos países, em tornos de pautas relativas à imigração, segurança pública, corrupção e políticas internacional. Nesse contexto, a atual crise planetária/sanitária originada pela pandemia do vírus Covid-19 reconfigura uma nova fase dessa quarta onda populista: ao mesmo tempo que temos a possibilidade de se observar as fragilidades no trato institucional de uma crise por parte do reacionarismo institucionalizado, temos o risco de uma guinada cada vez mais autoritária no controle dos corpos e da máquina pública, promovida por um pensamento ideológico propagado nas últimas décadas pelos mesmos gurus do apocalipse que influenciam diretamente lideranças da ultradireita global. Para fins desse ensaio, nos deteremos ao caso brasileiro dessa nova dinâmica social de modo a capturar o núcleo filosófico que compõe o Bolsonarismo. Para isso, apresentaremos três traços ou hipóteses dessa constelação obscurantista em sua dimensão social, geopolítica, e sobretudo ideológica, de modo apreender uma dimensão oculta da política sistemática de dominação em voga no evento pandêmico que eu denomino de "negacionismo viral exterminista".

\footnotetext{
2 THOMPSON, Notas sobre o exterminismo, o estágio final da civilização. In: THOMPSON, E. P. et al. Exterminismo e guerra fria, p. 43

${ }^{3}$ DANOWSKI; VIVEIROS, Há um mundo por vir?

4 BUSTAMANTE; MEYER, Bolsonarism E Covid-19: Truth Strikes Back

${ }^{5} \mathrm{MUDDE}$, Far right today
} 


\section{Internacional exterminista: tradicionalismo na rota do autoritarismo furtivo}

A primeira hipótese, a nível de diagnóstico social, identifica que a consolidação do protagonismo dessas lideranças neoconservadoras foi influenciada pela adoção de uma crítica obscurantista do progresso através da plataforma do "nacionalismo transnacional" que em nosso contexto proporcionou ao aparato negacionista viral dos governos de ultradireita a oportunidade de acelerarem o projeto exterminista solapando as instituições por dentro, sem uma ruptura institucional ou golpe declaro na prática de um autoritarismo furtivo. Isso implica afirmar que a ascensão da ultradireita nos governos e na esfera pública, ocorreu em parte pela erosão normativa das democracias liberais tendo como consequência a constituição de um campo iliberal, decorrente do rebote (backlash) ou refluxo conservador internacional no campo difuso da cultura. Essa mudança estrutural foi orquestrada por uma rede de ideólogos", uma espécie de "gramscianos de direita"6, contra forças progressistas (aqui representadas por políticas públicas de integração da sociedade civil, multiculturismo e democratização de formas de vida) que perderam legitimidade na crise do neoliberalismo por diversos fatores e deram espaço para ascensão de governos populistas de direita. Cabe investigar como foi dado tal redirecionamento intelectual e cultura da cena política.

É certo que muitos foram os governos autoritários e despóticos que, pelo menos desde a república de Weimar, foram acompanhados de um pensador e uma teoria capenga para legitimar a autoridade de determinado líder político ${ }^{7}$. A função de tais "intelectuais orgânicos" consiste, em princípio, em justificar as arbitrariedades de quem ele ou ela se aproveita para criar projeção e traduzir as mensagens do líder, com o intuito de criar vantagens estratégicas para seus adeptos no exercício do pequeno poder cotidiano. Raramente era considerado possível encontrar um núcleo filosófico compartilhado entre tais ideólogos, pois a justificativa de um discurso legitimatório do poder e sua filosofia subjacente variavam de acordo com a peculiaridade local da ideologia política. Contudo, a atual configuração da influência da ultradireita parece ser cada vez mais oriunda das diretrizes gerais de uma filosofia obscurantista em comum. Pois justamente as três figuras que se destacam como ideólogos dos maiores países do globo e que estão dispostos estrategicamente em três diferentes polos geográficos: Steve Bannon, ideólogo de Donald Trump e da alt-right nos EUA, Alexandr Durgin, conselheiro de Vladimir Putin e do eurasianismo na Rússia e Olavo de Carvalho, guru de Bolsonaro no Brasil e da nova direita cultural.

As afinidades eletivas que esses pensadores dispersos em diferentes territórios do mundo compartilham giram em torno da "formação filosófica" comum na vertente esotérica do tradicionalismo. Mas o que seria essa filosofia? Tradicionalismo é uma doutrina fundada por René Guenon, Julius Evola e Frithjof Schuon, traduzida numa filosofia perene que é a síntese ocultista de doutrinas orientais e da gnose clássica. Para compreender esse fenômeno de ideias "fora do lugar" nos remetemos ao livro "Against the modern world", de Mark Sedgwick ${ }^{8}$, no qual o autor traça de maneira competente

\footnotetext{
${ }^{6}$ Em chave similar de cartografia política, Beiner ressalta a influência do pensamento de Heidegger e Nietzsche em gurus da nova direita como Bannon e Dugin. Cf. BEINER, Dangerous Minds: Nietzsche, Heidegger, and the Return of the Far Right. Sobre novas figuras que operam na esfera pública, mas não necessariamente me governos, como Jordan Peterson, cf. ŽIŽEK, A left that dares to speak its name: 34 untimely interventions.

${ }^{7}$ O psicanalista Christian Dunker aponta como Roland Freisler cumpria essa função em Weimar, enquanto na guerra fria Joseph McCarthy era o representante norte-americano mais notório de uma direita radical e no stalinismo, o exemplo mais representativo era a figura controversa de Andrei Jdanov. Cf. DUNKER, Crer $e$ destruir: os intelectuais na máquina de guerra nazista da SS

${ }^{8}$ SEDWICK, Against the Modern World: Traditionalism and the Secret Intellectual History of the Twentieth Century.
} 
uma reconstrução da doutrina tradicionalista disposta em três componentes fundamentais: (a) o recurso à filosofia perene, isto é, a ideia segundo a qual a verdade presente na religião só pode ser alcançada por meio de um retorno ao núcleo autêntico da tradição religiosa; (b) a inversão do projeto moderno e seu ideal de progresso moral como uma fé supersticiosa na razão e na emancipação humana nos termos de uma recuperação de uma tradição pré-moderna fincada em valores orientais e espiritualistas; (c) a iniciação como um processo de recrutamento de uma elite metafísica como base catalisadora de um retorno do ocidente as suas origens espiritualistas. Essa regressão a um estado idílico, como ressalta Benjamin Teitelbaum ${ }^{9}$, apresenta um elemento regenerativo da civilização mediante a catástrofes humanamente induzidas: "o declínio da sociedade [...] refere-se à disseminação do materialismo e da homogeneização à custa da espiritualidade e da hierarquia (isso também explica por que o Tradicionalismo cultiva um anseio apocalíptico incomum)”. Afeito uma ordenação hierárquica e elitista da sociedade, no qual justificam uma divisão social de castas como naturalizada e intrínseca às estruturas políticas da sociedade, Guénon ${ }^{10}$ construiu uma seita filosófica espiritualista com o intuito de retomar uma nostalgia racista de castas superiores dominando as inferiores ${ }^{11}$.

Traduzida nos termos de uma concepção negativa, apocalíptica e anti-iluminista da história, nessa perspectiva retrógrada a democracia não é considerada o resultado de um processo de progresso moral da liberdade política, tampouco a realização do núcleo normativo da modernidade. Pelo contrário, a democracia liberal vista no ocidente é tomada como manifestação de decadência e desintegração dos valores da tradição que os levou na "Kali Yuga", uma idade das trevas decorrente do deslocamento da casta de escravos na sociedade por políticas de inclusão social. Para Guénon e outros tradicionalistas, somente via uma batalha com eliminação dessa casta inferior que poderíamos retornar à Idade Dourada, uma era na qual vigora uma ideia de pureza e nobreza da raça, muitas vezes associada ao arianismo.

Foi justamente essa tese de uma regressão que mobilizou Julius Évola ${ }^{12}$, um tradicionalista influente no fascismo italiano, que contribuiu com Mussolini, a associar uma consequência lógica do tradicionalismo ao fascismo: "O Fascismo se nos mostra como uma revolução reconstrutiva, dado que afirma um conceito aristocrático e espiritual da nação, oposto tanto ao coletivismo socialista e internacionalista quanto à noção democrática e demagógica da nação"13.

E é essa mesma doutrina de uma metafísica da guerra, que disputa uma guerra cultural, mas tem como foco não só a disputa por valores e normas sociais, mas a eliminação do inimigo - aqui entendido como aqueles que se integraram a sociedade e não correspondem aos ideias de pureza e ordem espiritual - que está presente nos

\footnotetext{
9 TEITELBAUM, War for Eternity. Inside Bannon's Far right circle of global power brokers. New York: Dey Street Books, 2020.

${ }^{10}$ GUÉNON, O rei do mundo

${ }^{11}$ Contra a democracia, Guénon argumenta que "o superior não pode proceder do inferior, porque o maior não pode proceder no menor; esta é uma absoluta certeza matemática que nada pode questionar. (...) O povo não pode conferir um poder que ele mesmo não possui; o verdadeiro poder somente pode vir de cima, e é por isso que ele apenas pode ser legitimado por algo pairando acima da ordem social, ou seja, por uma autoridade espiritual”. Cf. GUÉNON, René. A Crise do Mundo Moderno. São Paulo, Irget, 2009. GUÉNON, René. Formas Tradicionais e Ciclos Cósmicos. São Paulo, Irget, 2012.

${ }^{12}$ GUÉNON, Autoridade Espiritual e Poder Temporal

${ }^{13}$ EVOLA, Revolta Contra o Mundo Moderno. EVOLA, Metaphysics of war: Battle, victory \& death in the world of tradition
} 
documentários de formação e divulgação da produtora de Bannon ${ }^{14}$ e nos panfletos eurasianos de Dugin. Mas qual seria a especificidade desse pensamento retrógrado nos trópicos, e em especial no Brasil?

\section{Capítulo brasileiro do tradicionalismo: o ornitorrinco bolsolavista}

A segunda hipótese deste ensaio diz respeito ao poroso modo de apresentação do tradicionalismo tropical tal como está encrustado no tecido social da realidade brasileira e representada aqui pelo fenômeno do bolsolavismo: uma máquina de guerra cultural, compreendido aqui (i) em primeiro lugar, como uma "metafísica da guerra" enquanto guerra cultural local, forjada no revisionismo da repressão da ditadura militar e cultivada no exército em torno de uma obra, o Orvil. Tal doutrina foi levada a cabo por diferentes figuras como Brilhante Ulstra e foi introduzido pelos setores mais antidemocráticos do exército e popularizado via Ultra por Jair Bolsonaro e seu clã no campo difuso do milicianismo e neopetencostalismo (ii).

E, em segundo lugar, o fenômeno se apresenta como o resultado da união da constelação teórica do olavismo, isto é, do conjunto de autores conservadores que orbitam seu arsenal retórico e, sobretudo, do culto a figura de guru atribuída a Olavo de Carvalho, que transcende seu curso de filosofia e adentra o terreno da cultura troll da internet catapultada pelo antipetismo. O resultado dessa junção ideológica inaudita é esse ornitorrinco: uma pletora de "ideias fora do lugar" que formam um processo de contrarrevolução conservadora mobilizado por estado mafioso e miliciano, furtivamente autoritário ${ }^{15}$ que tem como justificação filosófica de seu ultraliberalismo econômico e de sua política exterminista, um tradicionalismo sui generis replicado na base de sustentação da internet por meio de um aparato midiático que replica as ideias olavistas. Isso posto, resta nos orientar pela seguinte questão: Quais seriam e de onde surgiram essas ideias que compõe tal fenômeno do bolsolavismo?

(i) Orvilismo: O primeiro elemento do bolsolavismo consiste na sua aproximação com o militarismo. O retorno nostálgico que o tradicionalismo à brasileira tem como base uma era de ouro da ditadura civil-militar iniciada com o golpe de 1964. Embora algumas frações tendem a ter delírios de um passado idílico do período imperial, elevando a lideranças políticas os membros remanescentes da família imperial que paradoxalmente, encarnam princípios do ultraliberalismo, a evocação do militarismo ditatorial continua sendo o modelo mais compatível com o modelo olavista. Aqui o olavismo se une ao "orvilismo", uma possível nomeação ao fenômeno que Castro Rocha ${ }^{16}$ apontou como sendo a transposição da doutrina da Lei de Segurança Nacional de 1969 como foi desenvolvida pela escola superior de guerra e que cimentou a possibilidade dos adversários políticos serem eliminados no Orvilin, livro ao contrário, por ser o oposto do projeto desenvolvido no "Brasil: Nunca Mais", de 1985.

Oposto pois se tratava não de uma denúncia das práticas sistemáticas tortura pelo estado ditatorial brasileiro a população, mas uma compilação no espírito anticomunista da guerra fria e da caça nacional dos militares por ativistas de esquerda, de supostos crimes e atentados organizados pela conspiração comunista no Brasil.

\footnotetext{
${ }^{14}$ HORNADAY, You can learn a lot about Steve Bannon by watching the films he made

15 PRZWORSKI, Crises of Democracy

${ }^{16}$ CASTRO ROCHA, João Cezar. Guerra cultural e retórica do ódio: Crônicas do Brasil. Rio de Janeiro: Caminhos Editora, 2020 (no prelo)

${ }^{17}$ MACIEL, Licio; NASCIMENTO, José Conegundes. Orvil: tentativas de tomada do poder
} 
Essas mais de 1000 páginas foram vetadas por José Sarney na época de sua elaboração, mas permaneceram no subsolo do exército, como um santo graal da repressão, mas tiveram, como revelado pelo próprio, contato com Olavo por ele ter participado nos anos 1990 de um projeto no exército, tendo sido influenciador e influenciado daqueles que seguem tal doutrina orvilista. A denúncia olavista relativa a uma ameaça permanente do marxismo cultural na história brasileira se coaduna com a tese orvilista $^{18}$ das quatro tentativas comunistas de dominação política: a $\mathbf{1}^{-}$teria ocorrido entre 1922-1954 com a Intentona Comunista de 1935 e o governo Vargas, a segunda entre 1954-1964 com o projeto trabalhista de Goulart, a terceira toma espaço com a resistência da esquerda durante a ditadura civil-militar brasileira entre 1967-1974.

É, no entanto, essa última fase da redemocratização e do fim da ditadura que é considerada por Olavo alicerçado no Orvil a mais perigosa e que exige um combate mais intenso por parte das forças conservadoras. Justamente porque nesse período que a esquerda teria migrado do combate de armas para uma estratégia de infiltração nos órgãos de cultura e educação, como a imprensa e a universidade, para perpetuar a "ameaça comunista"19.

Só que Bolsonaro, visto como "mau militar" pelo próprio Geisel e outros setores mais progressistas do exército (escola de Sorbonne), traduz a doutrina orvilista nos termos esdrúxulos do garimpismo, um milicianismo que se alicerçou em parcerias de conglomerados neopetencostais na reprodução da oportunista narrativa anticomunista $^{20}$. Cá está nossa versão tupiniquim da sociedade de rackets ${ }^{21}$. Aqui a teologia da prosperidade ${ }^{22}$ substitui tanto a ortodoxia cristã do "Tradição Família e Propriedade" da ditadura como solapou o islamismo do tradicionalismo original de Olavo com uma lógica belicista que lhe é própria ${ }^{23}$ : a singela formiguinha crente do smilinguido deu lugar as camisas de "exército de cristo" contra a pluralidade das formas de vida, em especial, a liberdade religiosa e sexual, em ações de intolerância explícita.

(ii) Olavismo: A segunda dimensão que forma o núcleo do bolsolavismo é seu pensamento elevado a projeto permanente de uma doutrina hegemônica na ultradireita brasileira. Pois, aproveitando as fissuras do peemedebismo ${ }^{24}$, Olavo assumiu a posição de intelectual mais influente no cenário brasileiro justamente em 2013, no ano de maior efervescência popular contra o sistema político dada as jornadas de junho e os protestos ao redor do país. Enquanto as seitas ultraliberais de institutos replicadores da doutrina da Escola de Chicago surfaram na crítica moralista a corrupção, ensejando o fenômeno do lavajatismo e logo da deposição da presidente Dilma Rousseff, Olavo

\footnotetext{
${ }^{18}$ Essa tese está nas páginas do Orvil mas é adaptada nos vídeos de divulgação, em especial o documentário 1964: O Brasil entre Armas e Livros da produtora olavista Brasil Paralelo. In: https://site.brasilparalelo.com.br/ ${ }^{19}$ No Orvil há citações de Gramsci, Marcuse e outros filósofos em suas "teorias da hegemonia da esquerda".

${ }^{20}$ Nesse caldeirão se misturam o paramilitarismo de Rio das Ostras; o projeto da Escola sem Partido; a bancada do BBB - Boi, bíblia e bala; a força militantes dos Caminhoneiros; o enfraquecido apoio após a saída de Moro do lawfare lavajatista; o neoliberalismo pinochetista de Guedes; o ultraliberalismo de Faria Lima; milícias neointegralistas herdeiras do anauê de Plínio Salgado Filho (os mesmos que tocaram fogo na produtora Porta dos Fundos); os Incels (celibatários involuntário que orquestratam o massacre de Suzano em fóruns de deep web como dogolohan); a rede ciborgue do gabinete do ódio (terça livre e outros blogueiros) entres outras aberrações da antipolítica.

${ }^{21}$ JAY, Martin. Splinters in Your Eye: Frankfurt School Provocations. New York: Verso Books, 2020

${ }^{22}$ ALMEIDA, Ronaldo de. 2019. "Bolsonaro presidente: Conservadorismo, evangélicos e a crise brasileira". Novos Estudos CEBRAP 38 (1): 185-213.

${ }^{23}$ MACEDO, Edir. Como Vencer Suas Guerras Pela Fé: descubra como enfrentar suas batalhas do dia a dia. Rio de Janeiro: Editora Unipro, 2018

${ }^{24}$ NOBRE, Marcos. Imobilismo em movimento: da abertura democrática ao governo Dilma. Companhia das Letras, São Paulo: 2013.
} 
mobilizou uma astuta estratégia de fornecer para a nova direita cultural uma constelação doutrinária chamada aqui doravante de "olavismo cultural". Olavo apropriou-se do formato de uma guerra cultural ${ }^{25}$, e de modo oportunista, aproveitou a mudança estrutural da esfera pública neoliberal com as crises mundiais, assumindo o papel de denúncia de sua inconsistência, dos paradoxos e contradições políticas do lulismo, estabelecendo por meio de sua crítica e de sua estrutura ideológica à direita cultural em torno de contrapúblicos conservadores ${ }^{26}$ e de uma atualização de um pensamento esotérico como a doutrina tradicionalista por meio de diagnósticos constantes da realidade nacional. Embora partissem de visões filosóficas, econômicas e políticas distintas, o que unia esse grupo era uma oposição ao caráter progressista, popular e inclusivo do ciclo do governo petista, mas também uma não-identificação com a tradição patrimonialista de partidos de centro-direita e da direita tradicional (ora compreendido sob a alcunha de peemedebismo) - movimento esse que gerou, como observamos atônitos nos últimos anos, a campanha pré-impeachment (20142016), e a reorientação do establishment da direita em torno do partido Novo, principalmente do PSC e PSL e de frações do MBL.

Tal combate a uma suposta hegemonia cultural do esquerdismo na sociedade civil (marcado pelos processos de redemocratização e do PSDB e PT no poder) e o antipetismo na arena institucional passou a ser motivado e ganhar certa inteligibilidade pelas teses defendidas por Olavo de Carvalho. Concomitantemente, essa tática foi posta em prática pelos intelectuais místicos e reacionários anteriormente citados, seja nas produtoras e estações de rádio direitistas de Bannon ou em livros e textos dirigidos aos extratos mais conservadores da Rússia por Dugin. Todavia, a especificidade de Olavo consiste no acúmulo e no pioneirismo em utilizar aparatos da mídia alternativa em um momento que a esquerda libertária dominava esse campo. Brevemente, podemos mencionar que em relação a formação e divulgação de seu pensamento, ao menos três fases marcam a trajetória olavista: a fase esotérica (1970-1990), a fase cultural (19922012), e a mais importante, a fase política-institucional (2013-2020).

A primeira fase diz respeito a sua decepção com a militância comunista e sua incursão nas seitas tradicionalistas ${ }^{27}$ e nos rituais e contribuições a revistas astrológicas, de ufologia, de esoterismo e filosofia perenialista em geral. A segunda fase é marcada pelo seu fracasso na carreira acadêmica e seu reposicionamento em intervenções de crítica cultural ${ }^{28}$ na esfera pública contra a "engenharia da desordem" das políticas públicas ensejaram a inclusão social de grupos subalternos, traduzidos pelo olavismo como variantes do projeto globalista do marxismo cultural: abortismo, gayzismo, racialismo, ecolatria, laicismo ${ }^{29}$ compõe o ataque contra as forças progressistas da sociedade. A última fase, atual e mais poderosa do pensamente olavista trata-se de

\footnotetext{
25 CARVALHO, Olavo de. A inversão revolucionária em ação - Cartas de um terráqueo ao planeta Brasil (Volume IV). Vide Editorial, 2015. p.50

${ }^{26}$ WARNER, Michael. Publics and Counterpublics. New York: Zone Books, 2002.

${ }^{27}$ CARVALHO, Heloisa de. BUGALHO, Henry. Meu Pai, o Guru do Presidente: a face ainda oculta de Olavo de Carvalho. São Paulo: Editora 247, 2020 Vale ler na produção esotérica desse período uma radical crítica tradicionalista a modernidade Cf. CARVALHO, Olavo de. Fronteiras da tradição. São Paulo: Nova Stella. 1986. CARVALHO, Olavo de. Questões de simbolismo astrológico. São Paulo: Speculum. 1983

${ }^{28}$ CARVALHO, Olavo de. A nova era e a revolução cultural: Fritjof Capra \& Antonio Gramsci. Rio de Janeiro: Instituto de Artes Liberais \& Stella Caymmi. 1994; CARVALHO, Olavo de. O imbecil coletivo: atualidades inculturais brasileiras. Rio de Janeiro: Faculdade da Cidade. 1996.; CARVALHO, Olavo de. Uma filosofia aristotélica da cultura. Rio de janeiro: Instituto de Artes Liberais. 1994.

${ }^{29}$ CARVAlHO, Olavo. O Mínimo que Você Precisa Saber para não Ser um Idiota, (Edição de Colecionador) Felipe Moura Brasil (org.), Rio de Janeiro: Record, p.488
} 
como sua doutrina é levada pelos filhos de Bolsonaro a composição do governo pelos seus discípulos, e no âmbito doutrinário, é encarregado às últimas consequências pelo seu discípulo Ernesto Araújo, um tradicionalista que radicalizou a nível institucional, aparelhando a diplomacia brasileira de uma política oriunda do ensinamento de seu mestre. Para Araújo, Olavo foi a primeira pessoa no mundo a ver "o globalismo como o resultado da globalização econômica, entender seus propósitos impiedosos e a começar a pensar em como derrubá-lo”. Foi somente com Bolsonaro que o país haveria deixado de ser comunista e passou ase tornar um país conservador, antiglobalista e nacionalista.

Essa mudança estrutural somente foi possível graças a Olavo de Carvalho, a operação Lava Jato e a figura de Jair Bolsonaro. Para Araújo ${ }^{30}$, trata-se de uma renovação messiânica da política nacional. Para isso, ele faz o trabalho sujo institucional para o seu mestre, aparelhando junto a Bolsonaro o governo federal ${ }^{31}$.

Em geral, é possível notar que as três caraterísticas elencada por Sedwick do tradicionalismo - nostalgia, antimodernismo e metafísica da guerra - podem ser encontradas em elementos locais que foram apropriados pelo olavismo cultural e são mobilizadas como uma política governamental bolsonarista direcionada a eliminação do inimigo. A dimensão nostálgica é gestada pelo saudosismo revisionista da ditadura militar e da censura e repressão do AI-5, ao passo que o elemento do antimodernismo é replicado nas políticas retrógradas e obscurantistas impulsionadas pelo campo neopetencostal e de sua saga contra a pluralidade de formas de vida e de sua concepção excludente de estado e políticas públicas; e, por último, a guerra cultural olavista assume o papel dessa elite metafísica, incendiada pela dinâmica da guerra, que reconduzira as nações para a sua origens espiritualistas. Feito esse apanhado, qual seria a vinculação prática, enquanto política de governo, entre olavismo e bolsonarismo durante o caso da pandemia da covid-19 no Brasil?

\section{A verdade sufocada libertará? Negacionismo viral e o presidencialismo de exterminação}

Por fim, a terceira hipótese está na anunciada na epígrafe deste ensaio: o discurso de Bolsonaro na embaixada brasileira nos EUA, diante de Trump e Bannon e ao lado de Olavo expressa que, no plano político, a lógica bolsonarista é aquela do exterminismo, da eliminação do inimigo, via recurso das forças armadas. Já sua estratégia de perpetuação no poder, assim como em outros governos da ultradireita, é representada pelo negacionismo, que em sua modulação viral cumpre um papel central na administração pública da pandemia da covid-19. Essa estratégia marca uma nova prática política, diferente dos governos tucanos e do lulopetismo: o deslocamento de

\footnotetext{
$3^{\circ}$ Para Araújo, um tradicionalista inveterado, "O Brasil passa por um renascimento político e espiritual, e o aspecto espiritual desse fenômeno é determinante; o aspecto político é apenas uma consequência. [...] No Brasil (pelo menos), o nacionalismo tornou-se o veículo da fé, a fé tornou-se a catalisadora do nacionalismo, e ambos desencadearam uma estimulante onda de liberdade e de novas possibilidades. In: ARAÚJO, Ernesto. Chegou o Comunavírus. https://www.metapoliticabrasil.com/post/chegou-o-comunav\%C3\%ADrus 22 de Abril, 2020.

${ }^{31}$ Não é à toa que o Itamaraty vem sendo aparelhado via FUNAG, a Assecom pelo gabinete do ódio, com justamente com discípulos do olavismo em diversos fronts: Italo Marsili, Ana Campagnolo, a produtora Brasil Paralelo e muitos canais de youtube da ultradireita, o site de notícia Brasil sem medo, Alexandre Costa, Flavio Morgenstern, Sergio Camargo, Abraham Weintraub, Osmar Terra, Filipe Araújo, todos contribuem com a guerra cultural no front bolsonarista
} 
um presidencialismo de coalisão para uma forma mais sintomática de governo: o presidencialismo de colisão, que teria como o filósofo Marcos Nobre insiste: no caos institucional como método ${ }^{32}$. A retórica permeada de atos falhos e lapsos entre a "mitagem" e a "lacração" 33 na verdade fazem parte de um núcleo de racionalidade no método caótico de perpetuação do poder de Bolsonaro calcada na batalha do olavismo e orvilismo contra tudo que represente um advento progressista na política nacional.

Tendo em vista que a base olavista sempre flertou com irracionalismo e pseudo-teorias contra as leis gerais da ciência modernas, no caso da pandemia, a realidade do vírus desde seu surto foi uma verdade inconveniente para o bolsolavismo: ambos negaram a existência do vírus quando ele já mostrava seu potencial de letalidade, relegando-o a uma conspiração ${ }^{34}$. Nada que fugisse do script do negacionismo praticado até então em suas variadas modalidades: o negacionismo climático contra aquecimento global e queimadas na Amazônia, negacionismo científico com antivacinas, o negacionismo do genocídio da população negra o racismo, assim como a violência sistemática contra setores LGBTs, ou até teses estapafúrdias do negacionismo espacial que endossa teoria do terraplanismo, todos essas expressões culminam no negacionismo viral, outrora contra AIDS, mas agora com a COVID-19 $9^{35}$

Durante a pandemia, diversos são os atos que colocam na trilha do governo Bolsonaro uma atualização da visão olavista do mundo: reprodução da paranoia racista contra o governo da China vinculando a raça ao vírus: o vírus chinês ${ }^{36}$; no caso brasileiro trocando a ocultação os dados das queimadas na Amazônia pela ocultação de dados de mortos pelo virtus; tornando inimigos aqueles que fazem divulgação científica no caso da questão das queimadas o diretor do INPE, no caso da pandemia os ministros as saúde Mandetta e Treich, que foram demitidos por divulgarem transparentemente dados não coadunarem a narrativa negacionista e foram taxados de alarmistas e mentirosos. É sintomático a fala de Mandetta quando foi demitido: "eu não fui demitido, demitida aqui foi a ciência”. Onde o movimento antivacina era propagado pela corja olavista, ele virou um movimento pró-cloroquina, como uma panaceia que, mesmo rejeitada pelos órgãos internacionais, continuou sendo produzida, distribuída pelo governo e pelo exercíto que hoje conta com uma quantidade suficiente para 18 anos de suprimento. É importante lembrar que no dia em que o Brasil completou quase 5.000 mortes pelo coronavirus, ao ser questionado Bolsonaro respondeu a seguinte emblemática frase: "E daí? Quer que eu faça o que? Sou Messias, mas não faço milagre". Ela vem no rol de muitas outras infelizes declarações: o desprezo pela letalidade do vírus o caracterizando como gripezinha e horrendas negligências com os cuidados públicos em relação ao vírus. Assim como Órban, Bolsonaro mobiliza esse realismo relutante fazendo uso da crise para colocar população sob controle de informação, vigiar inimigos, e relativizar mortes factuais como "histeria da imprensa", e fazer

\footnotetext{
${ }^{32}$ NOBRE, Marcos. Ponto-final: A guerra de Bolsonaro contra a democracia. São Paulo: Todavia, 2020.

33 ROCHA, Camila. MEDEIROS, Jonas. "Vão todos tomar no...": a política de choque e a esfera pública. Disponível em: www.horizonteaosul.com/2020/04/27/VAO-TODOS-TOMAR-NO-A-POLITICA-DOCHOQUE-E-A-ESFERA-PUBLICA. 2020. Acessado em 27.04.2020.

34 PHILIPS, Tom; BRISO, Caio Barretto (2020). «Bolsonaro's anti-science response to coronavirus appals Brazil's governors». The Guardian (em inglês). ISSN 0261-3077

35 KRUGMAN, Paul "Por que o negacionismo viral lembra o climático" Revista Exame. Acesso em 25 de abril de 2020

${ }^{36}$ HERDY, Thiago. "Isolamento é coisa de comunista": os zaps bolsonaristas durante a pandemia. Revista Época. (2020). Acesso em 28 de abril de 2020
} 
incitação criminosa para sua base invadir hospitais e fiscalizar UTI's assediando profissionais saúde, tornando cada vez mais claro um projeto neomalthusiano, típico de darwivinismo social, replicado na aposta eugenista de imunidade de rebanho que tem como função exterminista eliminar mais fracos e os inimigos do governo.

O projeto exterminista ressaltado pela "metafísica da guerra" é acelerado na pandemia nas manifestações apoiadas por Bolsonaro que clamam pela intervenção militar e pela retomada da luta armada dado o armamento da população e os motins das políticas militares estaduais. As "carreatas da morte" que pedem o fim do isolamento em nome de um patriotismo verde-amerelo, reedição de slogans neointegralistas, a adoção de símbolos pró-governos autoritários como bandeiras da ultradireita ucraniana em protestos pró-bolsonaristas que destroem cruzes em homenagem a mortos, e a milícia patrocinada e incentivada pelo gabinete de ódio do governo dos "3oo de Sarah Winter", revelam o caráter fascista do projeto bolsonarista durante a pandemia da covid-19, compactuando com a tipologia que o filósofo Jason Stanley ${ }^{37}$ sobre as dez características constitutivas desse pensamento retrógrado: (a) o recurso de uma nostalgia a um passado místico que glorifica uma estrutura de dominação social: seja um período de supremacia masculina ou racial e até mesmo um regime despótico como a ditadura militar no Brasil, (b) propaganda e a agitação fascista, (c) o Anti-intelectualismo, (d) a destruição da realidade e a relativização da verdade, compreendido hoje pela disseminação das fake-news, (e) a hierarquização da sociedade, (f) a vitimização de um grupo dominante, (g) disseminação de uma tensão sexual contra um grupo adversário que seria naturalmente imorais, (h) uma saga contra a ideologia de gênero e por último (i) um elogio ao trabalho ao modo nazista e uma acusação a todos contrários a essa teologia da prosperidade como vagabundos e preguiçosos que querem atravancar o avanço da nação. Enquanto Bannon reforça em seus documentários e produções radiofônicas como o seu programa "War Room" um catastrofismo regenador da espécie, Araújo, o olavista com mais acesso ao governo está aparelhando o Itamaraty, com a inclusão de César Alberto Ranquetat Júnior, um dos maiores seguidores do fascista Julius Evola no Brasil, preparando assim a base para a efetivação prática e intelectual da doutrina tradicionalista na política local e internacional contra o "comunavirus" 38 , isto é, "o vírus" que ameaça seu projeto contra as políticas progressistas. Retomando uma expressão de Virilio, Safatle ${ }^{39}$ descreve essa política como um "estado suicidário", um novo modelo de gestão do neoliberalismo, no qual existem "várias formas de destruir o estado e uma delas, a forma contrarrevolucionária, é acelerando em direção a sua própria catástrofe, mesmo que ela custe nossas vidas". Resta saber se essa catástrofe ira se efetivar: ou esse modelo estrará em crise $^{40}$ e as instituições e a sociedade civil unidos em um esforço antifascista conseguirá reverter esse horizonte exterminista para uma redemocratização efetiva da sociedade, ou, se esse evento pandêmico significar uma acentuação do projeto bolsolavista obscurantista, poderemos presenciar já no início desse século uma nova arquitetura da destruição.

\footnotetext{
37 STANLEY, Jason. Como funciona o fascismo: A política do “nós” e “eles”. LPM Pocket. 2018

${ }^{38} \mathrm{ARAUUJO}$ Ernesto. Chegou o Comunavírus. https://www.metapoliticabrasil.com/post/chegou-ocomunav\%C3\%ADrus 22 de Abril, 2020.

39 SAFATLE, Vladimir. Bem vindo ao Estado Suicidário. N-1 Edições, 2020.

$4^{\circ}$ SOLANO, Esher. ROCHA, Camila. Bolsonarismo em crise? FRIEDRICH-EBERT-STIFTUNG, São Paulo, 2020. In: https://www.fes-brasil.org/detalhe/bolsonarismo-em-crise/. Acesso em 05.06.2020.
} 


\section{Referências}

ALEXANDER, Jeffrey. Vociferando Contra o Iluminismo: a ideologia de Steve Bannon. Sociol. Antropol. Rio de Janeiro, v.o8, n. 03: p1009-1023, set.-dez., 2018

ALMEIDA, Ronaldo de. 2019. "Bolsonaro presidente: Conservadorismo, evangélicos e a crise brasileira”. Novos Estudos CEBRAP 38 (1): 185-213.

ADORNO, Theodor. Aspetos do Novo Radicalismo de Direita. Lisboa: Edições 70, 2020.

ARAÚJO, Ernesto. Chegou o Comunavírus. https://www.metapoliticabrasil.com/post/chegou-o-comunav\%C3\%ADrus Acesso em 22 de Abril, 2020.

ARAÚJO, Ernesto. Now we do: on politics and religion in Brazil after their recent presidential election. The New Criterion. Jan. 2019. Disponível em: https://www.newcriterion.com/issues/2019/1/now-we-do

BEINER, Ronald. Dangerous Minds: Nietzsche, Heidegger, and the Return of the Far Right. University of Pennsylvania Press, Philadelphia, 2018

BUSTAMANTE, Thomas da Rosa \& Meyer, Emilio Peluso Neder Bolsonarism E Covid-19: Truth Strikes Back, Int'l J. Const. L. Blog, Mar. 24. (2020), http://www.iconnectblog.com/2020/03/bolsonarism-and-covid-19-truth-strikes-back/

Acessado em: 24.04.2020

CARVALHO, Heloisa de. Bugalho, Henry. Meu Pai, o Guru do Presidente: a face ainda oculta de Olavo de Carvalho. São Paulo: Editora 247, 2020

CARVALHO, Olavo de. Fronteiras da tradição. São Paulo: Nova Stella. 1986

CARVALHO, Olavo de. O Mínimo que você precisa saber para não ser um idiota. Rio de Janeiro: Record, 2013

CARVALHO, Olavo de. A inversão revolucionária em ação - Cartas de um terráqueo ao planeta Brasil (Volume IV). Vide Editorial, 2015

CARVALHO, Olavo de. A nova era e a revolução cultural: Fritjof Capra \& Antonio Gramsci. Rio de Janeiro: Instituto de Artes Liberais \& Stella Caymmi. 1994

CARVALHO, Olavo de. O imbecil coletivo: atualidades inculturais brasileiras. Rio de Janeiro: Faculdade da Cidade. 1996.

CARVALHO, Olavo de. Uma filosofia aristotélica da cultura. Rio de janeiro: Instituto de Artes Liberais. 1994.

DANOWSKI, Déborah; VIVEIROS, Eduardo de Castro. Há um mundo por vir? Florianópolis: Cultura e Barbárie, 2016.

DUGIN, Alex. CARVALHO, Olavo. Os EUA e a nova ordem mundial São Paulo: Vide Editorial, 2012.

DUNKER, Christian. Olavo de Carvalho, o “ideólogo de Bolsonaro", contra o professor Haddad. Blog da Boitempo. 15/10/2018 https://blogdaboitempo.com.br/2018/10/15/olavo-decarvalho-o-ideologo-de-bolsonaro-contra-o-professor-haddad/

DUNKER, Christian. Crer e destruir: os intelectuais na máquina de guerra nazista da SS. Rio de Janeiro, Zahar: 2017.

EVOLA, Julius. Revolta Contra o Mundo Moderno. São Paulo: Irget, 1979. 
EVOLA, Julius. Metaphysics of war: Battle, victory \& death in the world of tradition. Londres: Arktos, 2011.

FELTRAN, Gabriel. The revolution we are living HAU: Journal of Ethnographic Theory. Volume 10, number 1, 2020

FINCHELSTEIN, Federico. A Brief History of Fascist Lies. University of California Press, 2020.

FRASE, Peter. Quatro futuros: a vida após o capitalismo. São Paulo: Autonomia Literária, 2020.

FRIEDMAN, Uri. The Coronavirus-Denial Movement Now Has a Leader. The Atlantic. https:/www.theatlantic.com/politics/archive/2020/o3/bolsonaro-coronavirus-denial-braziltrump/6o8926/

GUÉNON, René. O rei do mundo. Lisboa: Edições 70, 1991

GUÉNON, René. A Crise do Mundo Moderno. São Paulo, Irget, 2009

GUÉNON, René. Formas Tradicionais e Ciclos Cósmicos. São Paulo, Irget, 2012

GUÉNON, René. Autoridade Espiritual e Poder Temporal. S. Paulo, Irget, 2011

HERDY, Thiago 'Isolamento é coisa de comunista': os zaps bolsonaristas durante a pandemia. Revista Época. (2020). Consultado em 28 de abril de 2020

HORNADAY, Ann. You can learn a lot about Steve Bannon by watching the films he made. The Washington Post, 2 fev. 2017

HUNTER, Wendy, POWER, Timothy Bolsonaro and Brazil's Illiberal Backlash. Journal of Democracy v. 30, no. 1, 2019: 68-82

JAY, Martin. Splinters in Your Eye: Frankfurt School Provocations. New York: Verso Books, 2020

KRUGMAN, Paul. Por que o negacionismo viral lembra o climático. https://exame.abril.com.br/blog/paul-krugman/por-que-o-negacionismo-viral-lembra-oclim. Acessado em 23.04.2020

MACIEL, Licio; NASCIMENTO, José Conegundes. Orvil: tentativas de tomada do poder. Brasília: Editora Schoba, 2020.

MACEDO, Edir. Como Vencer Suas Guerras Pela Fé: descubra como enfrentar suas batalhas do dia a dia. Rio de Janeiro: Editora Unipro, 2018

MUDDE, Cas. Far right today. London: Polity Press, 2020

METEORO BRASIL (org.) Tudo o que você precisou desaprender para virar um idiota. São Paulo: Editora Planeta, 2019.

NOBRE, Marcos. Ponto-final: A guerra de Bolsonaro contra a democracia. São Paulo: Todavia, 2020.

NOBRE, Marcos. Choque de democracia. São Paulo: Companhia das Letras, 2015

NOBRE, Marcos. Imobilismo em movimento: da abertura democrática ao governo Dilma. Companhia das Letras, São Paulo: 2013.

PHILIPS, Tom; BRISO, Caio Barretto (2020). "Bolsonaro's anti-science response to coronavirus appals Brazil's governors". The Guardian (em inglês). ISSN 0261-3077 
PINHEIRO-MACHADO, Rosana. Brasil em transe: bolsonarismo, nova direita e desdemocratização. Oficina Raquel, 2019.

PRZWORSKI, Adam. Crises of Democracy. Cambridge University Press; 2019

ROCHA, Camila. MEDEIROS, Jonas. "Vão todos tomar no...”: a política de choque e a esfera pública. Disponível em: www.horizonteaosul.com/2020/04/27/VAO-TODOS-TOMAR-NOA-POLITICA-DO-CHOQUE-E-A-ESFERA-PUBLICA. 2020. Acessado em 27.04.2020.

ROCHA, Camila. "Menos Marx, mais Mises!”: uma Gênese da Nova Direita Brasileira. Tese de doutoramento. São Paulo: USP, 2019.

RICUPERO, Raquel; SOARES, Felipe. O Discurso Desinformativo sobre a Cura do COVID-19 no Twitter: Estudo de caso. Revista E-Compós, 2020.

SAFATLE, Vladimir. Bem vindo ao Estado Suicidário. N-1 Edições, 2020.

SEDGWICK, Mark. Against the Modern World: Traditionalism and the Secret Intellectual History of the Twentieth Century. Oxford University Press, 2004

SCHUON, Frithjof. O sentido das raças. IBRASA. 2002.

SEDGWICK, Mark. Against the Modern World: Traditionalism and the Secret Intellectual History of the Twentieth Century. Oxford University Press, 2004

STANLEY, Jason. Como funciona o fascismo: A política do "nós" e “eles". LPM Pocket. 2018

SOLANO, Esher. ROCHA, Camila. Bolsonarismo em crise? FRIEDRICH-EBERT-STIFTUNG, São Paulo, 2020. In: https://www.fes-brasil.org/detalhe/bolsonarismo-em-crise/. Acesso em 05.06.2020.

SOLANO, Esther. Crise da Democracia e extremismos de direita. ANÁLISE. nº 42/2018

TEITELBAUM, Benjamin. War for Eternity. Inside Bannon's Far right circle of global power brokers. New York: Dey Street Books, 2020.

THOMPSON, E. P. et al. Exterminismo e guerra fria. São Paulo: Brasiliense, 1985

WARNER, Michael. Publics and Counterpublics. New York: Zone Books, 2002

ŽIŽEK, Slavoj. A left that dares to speak its name: 34 untimely interventions. Medford, MA:

Polity, 2020. 